\title{
Using Focus Groups to Explore Sources of Self-Efficacy in Puerto Rican Preservice Teachers
}

\author{
Yitza A. Arcelay-Rojas \\ Walden University
}

\begin{abstract}
This article used focus groups to explore Puerto Rican preservice teachers' perceptions of sources of self-efficacy. The present study allowed, through a qualitative design, examination of the experiences of preservice teachers at the end of their student teaching practicum. The qualitative design and the use of the focus group technique provided insight into the main sources of their perceived self-efficacy through the self-assessment of their field experience. The beginning of the student teaching practicum provoked an intense process of emotions in which the preservice teachers needed support and guidance, particularly in aspects of planning, differentiation, and classroom management. The participants agreed that substantial feedback and guidance from cooperating teachers and university supervisors helped them being confident and increased their perceived self-efficacy by reducing the feelings of anxiety generated by the practicum.
\end{abstract}

Keywords: self-efficacy, focus groups, preservice teachers, elementary, qualitative

\section{Introduction}

Student teachers' beliefs about their teaching skills can affect how preservice teachers apply the content learned in their preparation program (Martins, Costa \& Onofre, 2015). Using the term perceived self-efficacy, Bandura (1997) documented how personal beliefs can influence individuals' decisions and defined the construct of perceived self-efficacy as the "beliefs in one's capabilities to organize and execute a course of action required to produce given attainments" (p. 3). Due to its role in teacher's effectiveness, perceived self-efficacy has been studied using assessment scales measuring four sources of self-efficacy proposed by Bandura (1986): verbal and social persuasion, affective states, vicarious experiences, and mastery experiences.

Research measuring self-efficacy has focused on applying quantitative methods. However, selfefficacy is a complex and multidimensional construct, and it is vital to study it in more depth, including its contextual and cultural influences (Kleinsasser, 2014; Phan \& Locke, 2015). Correspondingly, this concept should be considered using qualitative approaches to explore the sources of self-efficacy from the particular context of individual teachers, thus exploring contextual and cultural meanings (Siwatu, 2011; Wheatley, 2005). Therefore, the purpose of this qualitative study was to examine the sources of self-efficacy of elementary preservice teachers, at the end of their Educator Preparation Program (EPP), enrolled in their student teaching practicum at an accredited private university in the Commonwealth of Puerto Rico. The Department of Education of the Commonwealth of Puerto Rico (2005) established that the student teaching practicum is "the culminating laboratory experience, through which the student teacher assumes responsibility for the teaching of one or more subjects to groups of students at the elementary or secondary level” (p. 1).

Four research questions guided the study:

Research Question 1: How do preservice teachers describe the verbal and social persuasion received during their teaching practice? 
Research Question 2: How do preservice teachers describe their affective states as a teacher?

Research Question 3: How do preservice teachers describe vicarious experiences regarding their teacher role?

Research Question 4: How preservice teachers describe their mastery experiences regarding their teacher role?

\section{Sources of Self-Efficacy}

Social cognitive theory (Bandura, 1997) is the theoretical framework I used for analyzing the opinions and beliefs of preservice teachers. Based on the concept of self-efficacy, this theory proposes that, as part of human behavior, people develop and create self-perceptions (Usher \& Pajares, 2008). These, in turn, become the means by which people follow their goals and recognize what they are capable of doing to control their environment.

The beliefs that people have about themselves are essential for self-control and personal competence (Bandura, 1986, 1997). The theory states that individuals can evaluate their experiences and thought processes, and that self-reflection and beliefs about abilities can mediate behavior. The performance of a person is a product of the belief they may have about their skills, and sometimes these beliefs can be predictive of behavior. Among the beliefs that individuals use to control their environment are self-efficacy beliefs or perceived self-efficacy. In the context of this research, perceived self-efficacy for preservice teachers refers to the self-assessment they make regarding their capabilities to teach at the elementary level.

Bandura (1997) identified four sources of self-efficacy beliefs. The first source is social and verbal persuasion. Researchers of perceived self-efficacy, Usher and Pajares (2008) established that this comprises the positive feedback received while carrying out a task. In the case of preservice teachers, they need reinforcements and feedback from cooperating teachers and university supervisors. The second source of self-efficacy is the affective states. This source includes emotional and physiological states, and it comprises the feelings that arise in different situations where student teachers can demonstrate their skills (Usher \& Pajares, 2008). For example, a student may feel more anxious and less competent when the practice supervisor is present. Likewise, physical and emotional well being can reinforce perceived self-efficacy. The third source is vicarious experiences, or the observation of other people as role models. In this study, these experiences relate to observing other teachers, university professors and colleagues. Eccles, Midgley, and Adler (1984) noted that these social models influence more during transitional periods, as in the student teaching practicum. Successful mastery experiences are the fourth source and occur when the teacher has the opportunity to complete an experience effectively. In this way, the individual can see the results of their actions. The EPP's field experiences can represent this type of understanding and can be a catalyst for greater feelings of effectiveness in the classroom. Subsequently, teachers with a greater sense of selfefficacy believe they can achieve their goals (Usher \& Pajares, 2008).

In general, perceived self-efficacy affects behavior by (a) influencing what the individual chooses to pursue; (b) being a source of intrinsic motivation in carrying out tasks in which the teacher feels competent and confident or, in contrast, leading to avoidance of the tasks where they feel less confident; (c) determining the effort devoted to instructional strategies; and (d) predicting how long the individual will persevere in carrying out these activities (Bandura, 1997). These self-efficacy beliefs may also mediate the activities performed and the level of effort and persistence the person places in various activities (Bandura, 1986). For example, a teacher who has doubts about his or her ability to implement educational strategies to promote student achievement experiences a low selfefficacy, thus potentially avoiding the incorporation of these activities. On the other hand, if the 
individual has a high self-efficacy, researchers can infer from the theory that the individual would incorporate appropriate and effective teaching strategies. Moreover, the individual's level of accomplishment and perseverance in the face of obstacles is more significant. In general, the process by which the teacher acquires its self-efficacy includes (a) successful performance of teaching activities, strategies, and methods; (b) the individual's interpretation of these activities; and (c) the use of these interpretations to develop their beliefs.

\section{Education Preparation Program and Teacher's Self-Efficacy}

Providing significant opportunities for instruction, modeling, and feedback helps increase student teachers' self-efficacy during their formation (Darling-Hammond, 2006; Martins et al., 2015). Malinauskas (2017) also stated the importance of helping students to establish a high sense of selfefficacy during their preparation programs. Therefore, generating a sense of teaching self-efficacy during teacher formation is essential, especially when research has shown that teachers with high perceived self-efficacy have a better chance of success in the classroom (Mulholland \& Wallace, 2001; Ross \& Bruce, 2007, Usher \& Pajares, 2008; Woolfolk Hoy \& Burke Spero, 2005). In fact, highly effective teachers are more proactive in trying new teaching methods (Schwarzer \& Hallum, 2008) and show more enthusiasm and perseverance in their profession (Allinder, 1994; Colson, Sparks, Berridge, Frimming, \& Willis, 2017). Ashton and Webb (1986) found that effective teachers also described a positive perspective regarding their students' performance. Researchers have also found that effective teachers persevered on helping the most disadvantaged students by attending to their needs while building caring relationships with their students (Ross \& Bruce, 2007). In other words, teachers with high self-efficacy were more effective in promoting educational resiliency, defined as the student's "heightened likelihood of success in school and other life accomplishments despite environmental adversities brought about by early traits, conditions, and experiences" (Wang, Haertel, \& Walberg, 1994, p. 46).

Researchers have analyzed the relationship between self-efficacy and resilience. Pendergast, Garvis, and Keogh (2011) and Hong (2012) have emphasized that self-efficacy and resilience are related. According to Benard (2004) and Pfitzner-Eden (2016), the higher the sense of perceived self-efficacy, the greater the effort, persistence, and resilience. Yost (2006) found that teachers with a high sense of self-efficacy also exhibit higher levels of resilience, which allowed them to be committed to their profession. Yost carried out a qualitative study based on interviews and field observations from graduate teachers of an EPP. This study investigated the obstacles teachers encountered during their first year in teaching and what factors influenced their career. The findings showed the EPP contributions in promoting resilience and persistence in the teacher candidates. Participants noted that field experiences at the university level, in connection with the content, increased their selfefficacy in developing and applying a variety of instructional strategies during their practice. These findings concur with other researchers (e.g., Mulholland \& Wallace, 2001; Pfitzner-Eden, 2016) who have suggested that encouraging a higher perceived self-efficacy during the early stages of teacher preparation may have a greater impact on the educator's commitment to effective teaching.

\section{Method}

\section{Design}

I used the social constructivist perspective to guide this research; it is inductive and captures participants' perceptions. According to Creswell and Creswell (2018), the purpose of qualitative research is to understand the meanings that groups and individuals have regarding a human or social issue. Therefore, qualitative research seeks to describe how sociocultural complexities are interpreted, experienced, or understood in a particular context. Generally, the questions are broad, and I intended to explore the meaning of a situation. Merriam and Tisdell (2016) stated that 
qualitative methodology consists of a descriptive and discovery emphasis; its goal is interpreting the meaning of the experience. To this end, I selected the use of focus groups, which included open and follow-up questions, as the data collection technique for this study.

\section{Data Collection Technique}

Krueger and Casey (2014) explained that focus groups consist of a discussion that is carefully designed to obtain perceptions of participants on a given topic. These groups comprise individuals who have certain characteristics in common, and the objective is learning about the psychological and sociocultural group process. During the focus group interview, the moderator collects information on the feelings and opinions of individuals through the discussion of issues and experiences or from a given phenomenon.

Although there is no specific guidance on the number of focus groups, most studies organize at least two groups (Stewart \& Shamdasani, 2015). The number of focus groups depends on the topic, the questions, and the amount of information. Correspondingly, Krueger and Casey (2014) suggested that these groups should consist of four to 12 participants. Therefore, this study conducted two focus groups including a minimum of four elementary level preservice teachers. In the discussion sessions, I attempted to create an atmosphere of trust and encouraged self-reflection regarding sources of selfefficacy. Stewart and Shamdasani (2015) suggested that the sessions should last from 90 to $150 \mathrm{~min}$. In this study, I was the moderator and had previous experience in facilitating focus groups.

Evidence indicates that participants' perspectives are the result of their exchange of opinions, experiences, and various attitudes expressed through their views, and those perspectives develop through interaction with others (Krueger \& Casey, 2014; Stewart \& Shamdasani, 2015). The focus group technique allowed further exploration of the reasons and circumstances underlying a reply or a particular comment. The interview questions included the following categories: general background, verbal and social persuasion, affective states, vicarious experiences, and mastery experiences. I also examined the answers given using follow-up questions, which then revealed additional aspects or common experiences as a result of the participants' interaction. Table 1 presents the list of questions that guided the focus group interview.

Table 1. Focus Group's Interview Questions

\begin{tabular}{ll}
\hline Categories & \multicolumn{1}{c}{ Questions } \\
\hline General background & Why did you decide to study to become teachers? \\
& What do you consider to be the role of the teacher today? \\
Verbal and social persuasion & How do you describe the feedback you have received from your \\
& teachers, university supervisors, and cooperating teachers? \\
Affective states & How did you feel in the first classes you offered at the beginning \\
& of the practicum? \\
& How do you feel now when giving classes, as your student \\
& teaching practicum is about to end? \\
Vicarious experiences & Who do you identify as role models and as an influence in the \\
& way you teach? \\
In what ways have these role models influenced you? & \\
& Describe your experience during the teaching practice. \\
Mastery experiences & What educational strategies can you identify that you have \\
& applied satisfactorily in your teaching practice?
\end{tabular}




\section{Data Analysis}

After obtaining the written consent of the participants, I audio-recorded and transcribed the focus group discussions. My analytical process included the categorization of the answers, the extraction of general concepts, and the synthesis of the topics. To achieve a more direct connection with the data, I personally carried out the processes of transcription, categorization, and synthesis.

I transcribed the audio-recordings in full after each focus group session. This process allowed me to review the group dynamics, the opinions of participants, and the effectiveness of the questions used before starting the analysis of the second group. Some topics and comments made during the discussion, which could have gone unnoticed, were captured during the transcription process and its rereading. I assigned a unique code to each participant for the protection of their identity and to maintain confidentiality. This code consisted of a number and a capital letter, for example, $1 \mathrm{~A}$. In this example, the number represents the focus group, which is Group 1. The letter represents one of the participants corresponding to Group 1. This code identifies each citation, and it consists of a number and a letter, the area of specialization of the participant, and gender, either male or female.

The analysis of qualitative data was carried out simultaneously with the data collection (Merriam \& Tisdell, 2016). This allowed me to begin my analysis from the first interview session. Thus, although initial categories were established through the interview questions, the inductive process led to the consolidation of categories and the emergence of subcategories as part of the continuous comparison of common patterns through the data.

In the present study, I organized comments and responses according to the questions asked in the focus group sessions. First, I created a document in Microsoft Excel in which I copied all the answers of each group session, organized under the same question. Then, I read all the comments made by the participants to the same question and classified the most frequent answers among the groups, as well as those that could present a divergent comment to what other members of the group expressed. From there, central themes emerged which, through the iterative process of analysis, were consolidated into categories and subcategories of analysis.

There are multiple procedures for the analysis of the focus groups, and they all consist of a process of reduction and synthesis of the information offered in the group discussions (Krueger \& Casey, 2014; Merriam \& Tisdell, 2016). The analysis, grounded on the theoretical framework and the literature review, showed patterns of opinions (Merriam \& Tisdell, 2016; Yin, 2018) considering the frequency of themes. This process allowed organizing the discussion into subcategories according to the main idea expressed and in correspondence to the research question. The analysis also permitted a comparison between the participants' comments and the literature review. Table 2 presents the iterative process of themes, categories, and subcategories. It shows a breakdown of the emergent themes organized into categories and subcategories for analysis. 
Table 2. Emergent Themes Organized Into Categories and Subcategories for Analysis

\begin{tabular}{|c|c|c|c|}
\hline Research Questions & $\begin{array}{c}\text { Emergent } \\
\text { Themes }\end{array}$ & Categories & Subcategories \\
\hline $\begin{array}{l}\text { 1: How do preservice teachers } \\
\text { describe the verbal and social } \\
\text { persuasion received during } \\
\text { their teaching practice? }\end{array}$ & $\begin{array}{l}\text { Planning } \\
\text { Classroom } \\
\quad \text { management } \\
\text { Differentiation }\end{array}$ & $\begin{array}{l}\text { Verbal and social } \\
\text { persuasion }\end{array}$ & $\begin{array}{l}\text { Recommendations from } \\
\text { cooperating teachers } \\
\text { and supervisors }\end{array}$ \\
\hline $\begin{array}{l}\text { 2: How do preservice teachers } \\
\text { describe their affective states } \\
\text { as a teacher? }\end{array}$ & $\begin{array}{l}\text { Anxiety } \\
\text { Nervousness } \\
\text { Adaptability }\end{array}$ & Affective states & $\begin{array}{l}\text { Feelings generated by } \\
\text { the teaching } \\
\text { experience }\end{array}$ \\
\hline $\begin{array}{l}\text { 3: How preservice teachers } \\
\text { describe vicarious experiences } \\
\text { regarding their teacher role? }\end{array}$ & Role models & $\begin{array}{l}\text { Vicarious } \\
\quad \text { experiences }\end{array}$ & $\begin{array}{l}\text { Influence of teachers as } \\
\text { role models }\end{array}$ \\
\hline $\begin{array}{l}\text { 4: How preservice teachers } \\
\text { describe their mastery } \\
\text { experiences regarding their } \\
\text { teacher role? }\end{array}$ & $\begin{array}{l}\text { Application of } \\
\text { theory to real } \\
\text { context } \\
\text { Classroom } \\
\text { management } \\
\text { Planning }\end{array}$ & $\begin{array}{l}\text { Mastery } \\
\quad \text { experiences }\end{array}$ & Educational practices \\
\hline
\end{tabular}

\section{Participants}

The participants, selected from the group of preservice teachers, attended an accredited private university in the Commonwealth of Puerto Rico. According to Creswell and Poth (2018), a qualitative study includes a purposive sample. Consistently, the following criteria guided the campus selection: (a) accreditation and (b) graduation rate. First, this university received accreditation by the Middle States Association of Colleges and Schools and the EPP by the Teacher Education Accreditation Council. It also has a College of Education with respective departments of elementary and secondary education. Second, the campus' EPP had the highest percentage of graduates of education compared to other university campuses.

On the other hand, the maximum variation strategy entails that there is a representation of varied cases thus providing a wide range of perspectives on the situation under investigation (Bloomberg \& Volpe, 2016; Merriam \& Tisdell, 2016). To this end, the criteria used to select the participants were that they had to (a) be enrolled in the student teaching practicum, (b) represent the varied elementary level specializations, and (c) participate voluntarily. To this end, I identified the program directors who provided a list of the number of enrolled students and their specializations. Then, I visited the classrooms and made an announcement extending an invitation to students to participate voluntarily. I selected the participants according to their specializations and their availability.

I divided the participants $(N=9)$ into two groups. Group $1(n=5)$ consisted of three males and two females, and Group $2(n=4)$ consisted of all females. The specializations at the elementary level were as follows: general education $(n=1)$, language arts-English $(n=1)$, special education $(n=3)$, primary $(n=2)$, and arts $(n=2)$. All students were at the very end of their EPP, and I conducted the focus groups during the last week of their student teaching practicum, preceding graduation. Table 3 shows a description of the participants. 
Table 3. Description of Participants in Each Focus Group

\begin{tabular}{lcc}
\hline Participants & Specialization & Gender \\
\hline Group & & \\
1A & Special education & Female \\
1B & Special education & Male \\
1C & Special education & Male \\
1D & Arts & Female \\
1E & Arts & Male \\
Group 2 & & \\
2A & General education & Female \\
2B & Language arts & Female \\
2C & Primary & Female \\
2D & Primary & Female \\
\hline
\end{tabular}

\section{Findings}

\section{Verbal and Social Persuasion: Recommendations From Cooperating Teachers and Supervisors}

Verbal and social persuasion, in the form of feedback and support from cooperating teachers and university professors, were essential in influencing the participants' perceived self-efficacy. Participants agreed that support from cooperating teachers and university supervisors positively influenced them when they provided constant and substantial feedback, support, and communication to lessen the feelings of anxiety experienced by the teaching practice. One participant described her experience:

The first week was an adaptation; it was like, wow, nervous about making plans. The teacher tells me there are many students here and then specific problems. I have a minor in special education, and she recommended me using concrete things like pictures and objects ... Then, I became more relaxed. (2C, primary, female)

On the other hand, lack of feedback generated confusion and lack of guidance. As one student stated,

That first week, I saw the cooperating teacher making notes, and she said "excellent class," but I was not happy with the class outcomes. I was asking myself "where is she?" Why she kept saying "very good class" when I felt it was not, to me I did not like it. (2B, language arts, female)

Also, the participants identified areas for improvement recommended by their cooperating teachers and university supervisors. Areas for improvement included planning, voice/professional tone related to classroom management, and differentiation. This finding also was consistent with previous research by Martins et al. (2015), who identified these aspects as important areas of professional development in preservice teachers.

They indicated that feedback stated the need for strengthening their lesson plans. One participant expressed about his plans that "the cooperating teacher tells me I should plan more than one activity" (1C, special education, male). Another participant mentioned the importance of being consistent and establishing a lesson flow. She stated her cooperating teacher recommendation: "When you are going to implement something, keep it, do not change your concept, but rather follow a sequence, have a routine" (1D, arts, female). Also, some participants described how the feedback was related to their voice tone and classroom management: 
In my case the voice tone because I was very anxious and loud. It was the nerves, and then they were supervising me, and one child stopped and then the other one on the other side ... I am taking care of one of the children's doubts, and then I got out of control, but after that, I learned. (2C, primary, female)

Another participant agreed and mentioned,

I had the same recommendation ... the voice tone, in the first week, the second day I started teaching, the group was talking too much. I raised my voice a little, and they, even more, it was like a competition; then the teacher wrote on the recommendations: "next time, stay calm and tell them 'I stay quiet because I have manners." (2A, general education, female)

In addition, they indicated the challenge represented by the integration and diversity of special education students in the same classroom. For example, one candidate expressed, "at least to me, the supervisor emphasized a lot about goals and always try to remember that they are all different" (1A, special education, female). Similarly, a participant stated that feedback for him was about incorporating differentiation; he said his cooperating teacher asked him to "always keep an eye all the conditions I have, that although it is a group, it has to be individualized" (1B, special education, male).

\section{Affective States: Feelings Generated by the Teaching Experience}

All participants agreed that at the beginning of the field experience, they felt nervousness, anxiety, and panic, especially in their first week. A participant stated, "I agree, the first day you always feel the nerves. Because you do not know if the students will accept you, but nerves always were there" (1D, arts, female). Similarly, another described her experience like this:

My first week was very difficult because the group was testing me. I have a group that tends to be challenging, the vast majority of them; they're trying to test what is my limit; it was very difficult, but since the second week I established clear classroom rules... In fact, the cooperating teacher tells me, comparing from August to now, they have improved a lot. (2A, general education, female)

One participant described the anxiousness he felt at the beginning of the practicum,

Like everything unknown, it causes panic. My first day I was so nervous because it was something unknown, but it was quite easy for me to adapt after that. The key is to let the students know that I am the teacher. When you create that classroom management, then the rest will come with experience. (1B, special education, male)

Participants expressed the intensity of emotions they felt while teaching. All of them described the start of the field experience as difficult, and others used the adjective horrible. In this aspect, they highlighted two areas which generated these strong feelings: planning and classroom management. Four participants expressed anxiety during the planning process. Other participants mentioned that they felt stressed about how to achieve respect and rapport with their students. However, they were able to overcome initial frustration with the help of their cooperating teachers and supervisors. All participants agreed that at the beginning of the student teaching practicum, they experienced a high level of anxiety. However, at the end of the practicum, they expressed feeling satisfied, more secure and confident. With the recommendations of the cooperating teachers and supervisors, as well as the experience they acquired, they felt more confident at the end of practice. As one of them expressed,

I think the same way as my colleagues, the first days you always feel nervous because you do not know if the students will accept you. But, during this process, and during the classes, I 
felt more confident, I felt relaxed because I already know the students and I always have to remind myself that I am the teacher and that I am here to teach them and if they want me to listen to them, they have to listen to me because we all deserve respect. I think that's the most important thing. (1D, arts, female)

\section{Vicarious Experiences: Influences of Teachers as Role Models}

All participants identified several educators who, according to them, have influenced their teaching. One of them identified the influence he had from his parents, who are educators as well; he stated, "Some of my teachers including my father and my mother. Unfortunately, they are no longer with me, but my dad was principal, assistant superintendent, he was a teacher. My father was a great role model" (1E, arts, male). Others identified a college instructor who teaches at the EPP: "My teacher here who helped me and taught me to see the student, not as a student, but as a human being who feels and suffers, even though they cannot communicate that ... see them in a comprehensive way" (1B, special education, male). Similarly, a participant described the influence a university professor had in her learning process:

I would say a professor who was here at the University, which made me realize you've arrived at the university, and things here are different, and that dedication and the knowledge that she conveyed had such an impact on my life. (2B, language arts, female)

Eight participants were able to identify influential teachers in their life who inspired them to pursue the teaching profession. Participants described those teachers as dynamic because they incorporated varied teaching strategies, both in the classroom and in extracurricular activities. In the same way, the participants described these influential teachers as affective because they cared about them, motivated them to pursue their goals, encouraged high expectations for all students, and also exhibited a balance between trust and respect. As one participant explained,

I can say, a little bit of each teacher, because I have had good teachers all my life. My third grade teacher was very caring; she was like my second mom. My fourth grade math teacher who was dedicated to his work, responsible, he was prostudent, very good. My English teacher of seventh, eighth, 11th and 12th grade, a very dedicated teacher, I loved her classes, very dynamic, and many activities, and my cooperative teacher, I have an excellent cooperating teacher, and I hope to be like her. (2A, general education, female)

\section{Mastery Experiences: Educational Practices}

The participants identified various educational practices that they could apply successfully in the classroom. Some participants also referred to the use of positive reinforcement, individualized help, and incorporating different activities such as games and music to promote multiple intelligences. Participants also mentioned the incorporation of the responsive classroom technique. This technique includes beginning a class with the opportunity to share about themselves, to talk about the learning expected during the day, and to reflect on positive values. The participants emphasized that building a good relationship with and between the students was essential to their teaching practice. A teacher candidate expressed,

I think that when children see you with affection and see you as an example, that helps them a lot, because they will feel more comfortable in the classroom and more motivated to learn the material that you are giving them because they see that you are accepting them and you are recognizing the work they do, such as giving a positive word such as: "you did it very well." They like to see that what they do is valued. (1D, arts, female) 
This statement shows how successful mastery experiences, during the student teaching practicum, helped the candidates improve their confidence, especially when they were able to foster a positive relationship with their students. In both groups, the preservice teachers agreed on the importance of promoting values and the theme of establishing a caring relationship emerged. These features are consistent with Higgins (1994), who noted that effective teachers are accessible and caring. Similarly, these traits are related to a higher sense of perceived self-efficacy (Jamil, Downer, \& Pianta, 2012).

Preservice teachers can experience a reality shock. Kim and Cho (2012) described this concept as the "gap between what they learned in the teacher education program and the reality that they may face during the first year of teaching, with respect to the work of teaching the context in which teaching will occur" (p. 68). These authors also concluded that not being able to overcome this shock might contribute to a lower sense of confidence in teaching. The participants discussed how they were able to apply the theory to the real context although they recognized they also confronted a reality shock. A participant stated, "In college, we are taught how to teach theoretically, but the thing is very different when you are in the actual classroom; it is very different" (1E, arts, male).

Participants described how they were able to overcome this reality shock and how they gained confidence through getting to know their students and applying teaching techniques, taking into consideration the students' needs and preferences. A teacher candidate described her experience:

They really like playing games and the music, and the first 5 min of class we exercise or dance. They love to talk a lot, my classes instead of standing there in front and be talking and talking, I let them go discovering all. I only guide them letting them speak and speak. I'm there, I give them the idea and make them a lot of questions. (2A, general education, female)

Accordingly, Jamil and colleagues (2012) found that "preservice teachers who had more constructivist, democratic beliefs about how children learn felt more efficacious at the end of their preservice experience" (p. 131). One teacher candidate expressed, "I don't like being a teacher who is a dictator. I see a teacher yelling at a child, and I'm not that kind of person. I am strict, but... I like to be fair to the students" (1E, arts, male). In regards to classroom management, a participant stated, "They were very hyperactive today. However, yesterday were sweet, worked as a team, because I promote teamwork, the value of respect because now I have to include values in our teaching" (1A, special education, female). Echoing this value, another stated, "You have to give many activities because that's what they like" (2D, primary, female). The participants agreed that a constructivist approach was part of their teaching styles. According to Jamil and colleagues, this approach constitutes an important characteristic of effective teachers.

\section{Discussion}

All the participants agreed that they valued the feedback they received during the field experience, especially when it was specific and substantial. Meanwhile, a lack of it or fleeting comments made them felt lost or confused. These findings also concur with Fives, Hamman, and Olivarez (2007), who also found that experiencing substantial feedback and guidance positively influenced the student teacher confidence at the end of their practicum. According to Woolfolk Hoy and Burke Spero (2005) and Darling-Hammond (2006), it is essential to help preservice teachers establish a high sense of belief in their ability to educate starting at the EPP by facilitating significant opportunities of substantial feedback. These authors' findings also coincide with Thurlings, Vermeulen, Bastiaens, and Stijnen (2013), who found that feedback should be task oriented and specific. These authors also stated that effective feedback helps the students to "become familiar with the gap between an actual and desired performance and to close the gap" (p. 12). In this study, the participants expressed that 
they appreciated when their mentors provided direction and next steps for improving their teaching skills including planning, classroom management, and differentiation.

All the participants described the affective states generated during their field experience. They all agreed that at the beginning, they felt nervous because of their lack of experience. They had a range of feelings including anxiety, worries, and nervousness. Overcoming negative feelings including anxiety is an important aspect of perceived self-efficacy as well (Brígido, Borrachero, Bermejo, \& Mellado, 2013). However, some participants of Group 1 still showed hesitation. For example, one participant commented, "At first, it was not easy, little by little, I was adapting myself. Although I still get nerves" (1E, arts, male). This comment reflects certain beliefs of self-doubt at the end of the student teaching experience, and therefore, it is necessary to help students establish a strong sense of belief in their teaching ability (Woolfolk Hoy \& Burke Spero, 2005) because these beliefs may also mediate the level of effort and resilience (Bandura, 1986). Coaching teachers to develop strategies to manage emotions and set up a professional development plan to address perceived weaknesses could empower them through challenges and increase their perceived self-efficacy (Phan \& Locke, 2015).

Observing role models, such as university professors and colleagues, may constitute vicarious experiences that can influence the beliefs of teacher candidates during their teaching practice (Eccles et al., 1984; Pajares, 1996). In fact, all participants mentioned the influence of educators who, according to them, were role models. Although most candidates mentioned elementary or secondary school teachers, two participants mentioned university professors who inspired them to continue in the teaching profession. This influence is consistent with the literature (Crosnoe \& Elder, 2004; Henderson, Benard, \& Sharp-Light, 2007; Henderson \& Milstein, 2003; Werner, 1992), which indicates the importance of significant role models in promoting perseverance and resilience, especially during transitional periods such as the student teaching practicum.

At the end of their practicum, the preservice teachers described their experience as successful. Although at the beginning, they had many challenges, they were able to implement strategies such as collaborative learning, games, positive reinforcement, and classroom discussions. They felt their students responded positively to those strategies, and they observed progress in their students' learning. This progress empowered participants, and they felt more confident and with a higher perceived self-efficacy at the end of the experience. As one participant explained, "At the end, I felt less anxious, and I noticed an improvement in my students as well" (2C, primary, female). They also agreed how appropriate planning is essential in attaining teaching and learning goals and reducing their anxiety in the classroom. They emphasized that they also received much feedback in planning aspects and they could benefit from more training in this area. In fact, proper planning can create the conditions for mastery experiences as well (Martins et al., 2015).

\section{Conclusions and Implications for Practice}

The present study explored the experiences of a group of nine teacher candidates at the end of their student teaching practicum. This culminating field experience was central to self-efficacy development. It created an intense process of emotions in which the preservice teachers needed support and direction, in particular regarding aspects of planning, differentiation, and classroom management. The participants expressed the importance of receiving more training and practice in these areas. They also agreed that the support of cooperating teachers and practice supervisors could also be influential factors if they provide feedback and constant communication with the purpose of reducing the feelings of anxiety produced by the experience of teaching practice.

The findings also suggest that EPPs should consider the design of quality student teaching experiences and training which result in teachers who are more confident and cultivate a higher sense of perceived self-efficacy. Therefore, I recommend exposing the teacher candidates to more 
comprehensive field experience and coaching. A comprehensive student teaching practicum can increase preservice teachers' perceived self-efficacy (Malinauskas, 2017). Also, the implementation of discussion groups at the beginning, during, and at the end of the teaching practicum seminars and field experiences, aimed at helping the students reduce the feelings of anxiety caused by the teaching practice, can promote resiliency (Benard, 2004). The goal should be designing quality student teaching field experiences that result in teachers who are more prepared for the reality of teaching. In this aspect, it is recommended the development of emotional supports programs that also help the prospective teacher develop emotional competence (Brígido et al., 2013).

Mentors, including cooperating teachers and university supervisors, can help increase the beliefs of self-efficacy in their mentees (Hamman et al., 2006). The participants described their teachers and university professors who influenced their perceived self-efficacy as affective, because their role models actively cared, believed in each student's ability to achieve, and showed affection toward their students. Also, they described them as creative because they incorporated various educational activities and planned extracurricular activities that enriched the educational experiences of their students. These characteristics helped the preservice teachers in different stages of their studies and motivated them in pursuing the teaching career. Also, the relationship with students appeared to be fundamental for these preservice teachers. They described successful experiences in building a positive relationship between students and in implementing teaching strategies. These successful mastery experiences helped them appreciate their teaching role and feel more confident.

There are limitations to the present study. The findings are limited to preservice teachers who participated in this study and only allow conclusions applicable to them. Also, further research is necessary to reveal how self-efficacy evolves after the first year of experience in the teaching profession. More research is needed to explore the opinion of cooperating teachers and university supervisors as well, regarding their perception of their mentees' efficacy and how they perceive their role in promoting the mentee's perceived self-efficacy. Longitudinal studies are desirable in understanding changes in self-efficacy related to context, time, and experience. These studies could include individual or follow-up interviews with the participants to explore how self-efficacy changes with experience.

\section{References}

Allinder, R. M. (1994). The relationship between efficacy and the instructional practices of special education teachers and consultants. Teacher Education and Special Education, 17, 86-95. doi:10.1177/088840649401700203

Ashton, P., \& Webb, R. (1986). Making a difference: Teachers' sense of efficacy and student achievement. New York, NY: Longman.

Bandura, A. (1986). Social foundations of thought and action. New York, NY: Prentice-Hall.

Bandura, A. (1997). Self-efficacy: The exercise of control. New York, NY: W. H. Freeman.

Benard, B. (2004). Resiliency: What we have learned. San Francisco, CA: WestEd.

Bloomberg, L., \& Volpe, M. (2016). Completing your qualitative dissertation: A roadmap from beginning to end (3rd ed.). Thousand Oaks, CA: Sage.

Brígido, M., Borrachero, A. B., Bermejo, M. L., \& Mellado, V. (2013). Prospective primary teachers' self-efficacy and emotions in science teaching. European Journal of Teacher Education, 36, 200-217. doi:10.1080/02619768.2012.686993

Colson, T., Sparks, K., Berridge, G., Frimming, R., \& Willis, C. (2017). Pre-service teachers and selfefficacy: A study in contrast. Discourse and Communication for Sustainable Education, 8, 66-76. doi:10.1515/dcse-2017-0016 
Creswell, J. W., \& Creswell, J. D. (2018). Research design: Qualitative, quantitative and mixed methods approaches (5th ed.). Thousand Oaks, CA: Sage.

Creswell, J. W., \& Poth, C. N. (2018). Qualitative inquiry and research design: Choosing among five approaches (4th ed.). Thousand Oaks, CA: Sage.

Crosnoe, R., \& Elder, G. (2004). Family dynamics, supportive relationships, and educational resilience during adolescence. Journal of Family Issues, 25, 571-602. doi:10.1177/0192513x03258307

Darling-Hammond, L. (2006). Assessing teacher education: The usefulness of multiple measures for assessing program outcomes. Journal of Teacher Education, 57, 120-138. doi:10.1177/0022487105283796

Department of Education of the Commonwealth of Puerto Rico. (2005). Normas que regulan la organización e implantación de los centros de práctica docente (Carta circular 10-2004-2005) [Guidelines for the organization and implementation of student teaching centers (Policy 102004-2005)]. Retrieved from http://educon.uprm.edu/formularios/MaterialEstudiantesPPMES/CartaCircularDE10-0405.pdf

Eccles, J., Midgley, C., \& Adler, T. (1984). Grade-related changes in the school environment: Effects of achievement motivation. In J. G. Nicholls (Ed.), The development of achievement motivation (pp. 283-331). Greenwich, CT: JAI.

Fives, H., Hamman, D., \& Olivarez, A. (2007). Does burnout begin during student teaching? Analyzing efficacy, burnout, and support during the student teaching semester. Teaching and Teacher Education, 23, 916-934. doi:10.1016/j.tate.2006.03.013

Hamman, D., Olivarez, A., Lesley, M., Button, K., Chan, Y., Griffith, R., \& Elliot, S. (2006). Pedagogical influence of interaction with cooperating teachers on the efficacy beliefs of student teachers. The Teacher Educator, 42, 15-29. doi:10.1080/08878730609555391

Henderson, N., Benard, B., \& Sharp-Light, N. (2007). Resiliency in action: Practical ideas for overcoming risks and building strengths in youth, families, and communities. Ojai, CA: Resiliency in Action, Inc.

Henderson, N., \& Milstein, M. (2003). Resiliency in schools: Making it happen for students and teachers. Thousand Oaks, CA: Corwin Press.

Higgins, G. (1994). Resilient adults: Overcoming a cruel past. San Francisco, CA: Jossey-Bass.

Hong, J. Y. (2012). Why do some beginning teachers leave the school, and others stay? Understanding teacher resilience through psychological lenses. Teachers and Teaching, 18, 417-440. doi:10.1080/13540602.2012.696044

Jamil, F. M., Downer, J. T., \& Pianta, R. C. (2012). Association of pre-service teachers' performance, personality, and beliefs with teacher self-efficacy at program completion. Teacher Education Quarterly, 39, 119-138. Retrieved from https://files.eric.ed.gov/fulltext/EJ1001446.pdf

Kim, H., \& Cho, Y. (2012). Pre-service teachers' motivation, sense of teaching efficacy, and expectation of reality shock. Asia-Pacific Journal of Teacher Education, 42, 67-81. doi:10.1080/1359866X.2013.855999

Kleinsasser, R. C. (2014). Teacher efficacy in teaching and teacher education. Teaching and Teacher Education, 44, 168-179. doi:10.1016/j.tate.2014.07.007

Krueger, R., \& Casey, M. (2014). Focus groups: A practical guide for applied research. (5th ed.). Thousand Oaks, CA: Sage. 
Malinauskas, R. K. (2017). Enhancing of self-efficacy in teacher education students. European Journal of Contemporary Education, 6, 732-738. doi:10.13187/ejced.2017.4.732

Martins, M., Costa, J., \& Onofre, M. (2015). Practicum experiences as sources of pre-service teachers' self-efficacy. European Journal of Teacher Education, 38, 263-279. doi:10.1080/02619768.2014.968705

Merriam, S. B., \& Tisdell, E. J. (2016). Qualitative research: A guide to design and implementation. (4th ed.). San Francisco, CA: Jossey-Bass.

Mulholland, J., \& Wallace, J. (2001). Teacher induction and elementary science teaching: Enhancing efficacy. Teaching and Teacher Education, 17, 241-261. doi:10.1016/S0742-051X(00)00054-8

Pajares, F. (1996). Self-efficacy beliefs in academic settings. Review of Educational Research, 66, 543-578. doi:10.3102/00346543066004543

Pendergast, D., Garvis, S., \& Keogh, J. (2011). Pre-service student-teacher self-efficacy beliefs: An insight into the making of teachers. Australian Journal of Teacher Education, 36, 45-58. doi:10.14221/ajte.2011v36n12

Pfitzner-Eden, F. (2016). I feel less confident so I quit? Do true changes in teacher self-efficacy predict changes in preservice teachers' intention to quit their teaching degree? Teaching and Teacher Education, 55, 240-254. doi:10.1016/j.tate.2016.01.018

Phan, N. T., \& Locke, T. (2015). Sources of self-efficacy of Vietnamese EFL teachers: A qualitative study. Teaching and Teacher Education, 52, 73-82. doi:10.1016/j.tate.2015.09.006

Ross, J., \& Bruce, C. (2007). Professional development effects on teacher efficacy: Results of a randomized field trial. The Journal of Educational Research, 101, 50-60. doi:10.3200/JOER.101.1.50-60

Schwarzer, R., \& Hallum, S. (2008). Perceived teacher self-efficacy as a predictor of job stress and burnout: Mediation analyses. Applied Psychology: An International Review, 57, 152-171. doi:10.1111/j.1464-0597.2008.00359.x

Siwatu, K. O. (2011). Preservice teachers' sense of preparedness and self-efficacy to teach in America's urban and suburban schools: Does context matter? Teaching and Teacher Education, 27, 357-365. doi:10.1016/j.tate.2010.09.004

Stewart, D., \& Shamdasani, P. (2015). Focus groups: Theory and practice (3rd ed.). Thousand Oaks, CA: Sage.

Thurlings, M. M., Vermeulen, M. M., Bastiaens, T. T., \& Stijnen, S. S. (2013). Understanding feedback: A learning theory perspective. Educational Research Review, 9, 1-15. doi:10.1016/j.edurev.2012.11.004

Usher, E., \& Pajares, F. (2008). Sources of self-efficacy in school: Critical review of the literature and future directions. Review of Educational Research, 78, 751-796. doi:10.3102/0034654308321456

Wang, M., Haertel, G., \& Walberg, H. (1994). Educational resilience in inner cities. In M. C. Wang \& E. Gordon (Eds.), Educational resilience in inner-city America: Challenges amid prospects (pp. 45-72). Hillsdale, NJ: Lawrence Erlbaum Associates.

Werner, E. (1992). The children of Kauai: Resiliency and recovery in adolescence and adulthood. Journal of Adolescent Health, 13, 162-268. doi:10.1016/1054-139X(92)90157-7

Wheatley, K. (2005). The case for reconceptualizing teacher efficacy research. Teaching and Teacher Education, 21, 747-766. doi:10.1016/j.tate.2005.05.009 
Woolfolk Hoy, A., \& Burke Spero, R. (2005). Changes in teacher efficacy during the early years of teaching: A comparison of four measures. Teaching and Teacher Education, 21, 343-356. doi:10.1016/j.tate.2005.01.007

Yin, R. (2018). Case study research: Design and methods (6th ed.). Los Angeles, CA: Sage.

Yost, D. (2006). Reflection and self-efficacy: Enhancing the retention of qualified teachers from a teacher education perspective. Teacher Education Quarterly, 33, 59-76. Retrieved from http://www.jstor.org/stable/23478871

The Journal of Educational Research and Practice provides a forum for studies and dialogue that allows readers to better develop social change in the field of education and learning. Journal content may focus on educational issues of all ages and in all settings. It also presents peer-reviewed commentaries, book reviews, interviews of prominent individuals, and additional content. The objectives: We publish research and related content that examines current relevant educational issues and processes aimed at presenting readers with knowledge and showing how that knowledge can be used to impact social change in educational or learning environments. Additional content provides an opportunity for scholarly and professional dialogue regarding that content's usefulness in expanding the body of scholarly knowledge and increasing readers' effectiveness as educators. The journal also focuses on facilitating the activities of both researcher-practitioners and practitioner-researchers, providing optimal opportunities for interdisciplinary and collaborative thought through blogging and other communications.

Walden University Publishing: http://www.publishing.waldenu.edu 